\title{
PENGUATAN PERAN MASYARAKAT DALAM MITIGASI DAN ADAPTASI TERHADAP WABAH COVID-19 DI KABUPATEN BUTON
}

\author{
${ }^{1}$ Muhamad Handoyo Sahumena*, ${ }^{2}$ Mistriyani, ${ }^{3}$ Ruslin, ${ }^{4}$ La Aba, ${ }^{5}$ Syahbuddin \\ ${ }^{123}$ Fakultas Farmasi, Universitas Halu Oleo \\ ${ }^{4}$ Fakultas Matematika dan Ilmu Pengetahuan Alam, Universitas Halu Oleo \\ ${ }^{5}$ Fakultas Keguruan dan Ilmu Pendidikan, Universitas Halu Oleo \\ * corresponding author: handoyosahumena@gmail.com
}

\begin{abstract}
RINGKASAN
Covid-19 merupakan salah satu jenis virus terbaru dari keluarga corona virus yang saat ini tengah mewabah diseluruh dunia, tak terkecuali indonesia. Covid-19 tidak mempengaruhi kesehatan manusia, namun juga telah menyebabkan segala bentuk aktivitas, ekonomi, politik hingga pendidikan terhambat. Tujuan pengabdian ini adalah untuk memberikan pengetahuan mitigasi dan adaptasi mengantisipasi penyebaran Covid-19 khususnya di wilayah kabupaten Buton. Metode yang digunakan dalam pengabdian ini adalah sosialisasi baik secara daring, penyebaran leaflet secara langsung maupun media masa tentang perilaku hidup bersih dan sehat, pembuatan antiseptik dan desinfektan alami, serta pengenalan TOGA di Kabupaten Buton. Hasil pengabdian ini adalah warga desa di Kabupaten Buton memiliki pengetahuan dan kemampuan mitigasi dan adaptasi dalam menghadapi wabah Covid-19, serta lebih waspada dan tenang dalam menghadapi pandemic.
\end{abstract}

Kata kunci: Sosialisasi; Mitigasi; Adaptasi; Covid-19

\section{A. Analisis Situasi}

Coronavirus merupakan virus yang dapat menyebabkan penyakit pada manusia maupun hewan. Middle East Respiratory Syndrom (MERS) dan Severa Acute Respiratory Syndrome (SARS) merupakan infeksi saluran pernapasan manusia yang disebabkan oleh jenis coronavirus. Pada akhir 2019, dunia dikejutkan dengan temuan penyakit infeksi saluran pernapasan yang diakibatkan oleh coronavirus jenis baru yang disebut Coronovirus Disease 2019 (Covid-19). Covid-19 diduga merupakan jenis coronavirus yang berasal dari kelelawar namun secara mengejutkan mampu menginfeksi manusia. Kasus pertama Covid-19 ditemukan di Wuhan, Cina dan terus menyebar keberbagai belahan dunia termasuk Indonesia hingga akhirnya WHO menetapkan status Pendemi Global 
Covid-19 (WHO, 2020). Covid-19 menyebar melalui droplet/percikan yang dikeluarkan oleh seorang penderita saat batuk atau bersin. Gejala awal manusia terinfeksi virus adalah demam ringan dan batuk. Namun kondisi ini akan semakin parah setelah 2 minggu terinfeksi hingga dapat menyebabkan kematian jika tidak ditangani secara cepat dan tepat (Kemenkes, 2020).

Angka kejadian penyakit Covid-19 di seluruh dunia terus meningkat hingga mencapai jutaan penderita. Di Indonesia sendiri, hingga 18 Juli 2020 angka kejadian positif Covid-19 telah menyentuh angka 84.882 kasus (Satgas Covid, 2020). Angka ini diprediksi akan terus bertambah melihat tren kenaikan jumlah orang yang terinfeksi semakin meningkat dari waktu ke waktu. Oleh karena itu perlu penanganan yang khusus dalam pengahdapi wabah Covid-19.

Penanganan Covid-19 di Indonesia dengan beberapa negara lain agak berbeda. Jika di negara lain menerapkan lockdown, Indonesia menerapkan Pembatasan Sosial Berskala Besar (PSBB). Melalui Permenkes Nomor 9 tahun 2020, pemerintah menetapkan kebijakan Pedoman PSBB dalam rangka Percepatan Penanganan Covid-19. Tindakan preventif dan kuratif perlu dilakukan untuk mencegah penyebaran Covid-19. Beberapa tindakan pencegahan yang dapat dilakukan diantaranya menerapkan pola hidup bersih dan sehat, senantiasa menggunakan masker, serta menjaga daya tahan tubuh dengan berolahraga secara rutin serta mengkonsumsi makanan atau multivitamin yang dapat meningkatkan sistem imun tubuh.

Selain dampak kesehatan, Covid-19 juga telah menyebabkan segala bentuk aktivitas sosial, ekonomi, politik, hingga pada skala pendidikan menjadi terhambat. Kebijakan pemerintah yang sejak awal april lalu telah menerapkan pembatasan sosial berskala besar (PSBB) di seluruh wilayah-wilayah terdampak, dan menyarankan kepada seluruh rakyat indonesia agar stay at home khususnya masyarakat kabupaten buton. Hingga seluruh aktivitas yang biasa dilakukan secara langsung menjadi via daring atau online.

Berdasarkan latar belakang tersebut, maka tim pengabdian merasa terpanggil memberikan berkontribusi di tengah-tengah masyarakat pada masa pandemi ini, 
khususnya di wilayah kabupaten Buton. Tim pengabdian bersinergi bersama masyarakat dan pemerintah setempat bersinergi melakukan pengabdian dengan tema "Penguatan peran Warga Masyarakat dalam Mitigasi dan Adaptasi Menghadapi Wabah Covid-19 di Kabupaten Buton".

\section{B. Metode Pelaksanaan}

Pengabdian masyarakat ini dilaksanakan mulai Tanggal 15 Juni-12 Juli 2020, bertempat di Kabupaten Buton. Metode pengabdian yang digunakan dalam kegiatan ini adalah sosialisasi. Tahapan pelaksanaan pengabdian ini dibagi 3 yaitu:

\section{Tahap Persiapan}

Persiapan dengan analisis situasi yang bertujuan untuk mengidentifikasi dan mengumpulkan informasi awal mengenai bagaimana sikap masyarakat dalam menyikapi wabah covid-19. Setelah mengetahui kondisi daerah pengabdian maka dilanjutkan dengan penyusunan program.

\section{Tahap Pelaksanaan}

Memberikan sosialisasi mengenai covid-19 dan cara mengantisipasi penyebaran covid-19. Sosialisasi dilakukan secara daring dalam bentuk, pembagian leaflet, video, media cetak elektronik maupun nonelektronik serta grup media sosial. Materi sosialisasi meliputi edukasi pencegahan untuk mengatasi dilakukan penyebaran covid19, sosialisasi mengenai perilaku hidup bersih dan sehat, penggunaan masker yang tepat, pembuatan antiseptik dan desinfektan alami, pembuatan tempat cuci tangan, pembagian handsanitizer dan masker, serta pengenalan TOGA pada masyarakat di Kabupaten Buton. Keseluruhan kegiatan dilaksanakan dengan mematuhi protokol kesehatan covid-19.

\section{Tahap Evaluasi}

Evaluasi pelaksanaan program kegiatan ini dilaksanakan dengan terus membangun komunikasi dan memberikan informasi-informasi yang penting pada warga masyarakat Buton melalui media sosial.

\section{Hasil dan Pembahasan}


Desa Wabula, Kecamatan Wabula, Kabupaten Buton, Sulawesi Tenggara. Pelaksanaan kegiatan ini terbagi menjadi dua kegiatan utama yaitu persiapan serta pelaksanaan. Persiapan bertujuan untuk memperkenalkan kegiatan yang akan dilakukan terhadap masyarakat di wilayah kabupaten Buton, khususnya di Desa Wabula, Kecamatan Wabula, melihat kondisi sosial warga baik dari segi pendidikan, pekerjaan dan ekonomi, serta untuk mengidentifikasi dan memetakan masalah yang ada di wilayah pengabdian khususnya dalam menghadapi wabah Covid-19. Hal ini sangat penting sebagai dasar dalam menyusun program pengabdian. Beberapa masalah yang ditemukan di wilayah pengabdian diantaranya:

1. Kurangnya kesadaran masyarakat dalam menerapkan pola hidup bersih dan sehat,

2. Kurangnya pemahaman masyarakat terhadap berbagai aktifitas yang dapat meningkatkan sitem imun seperti berolahraga

3. Kurangnya masyarakat yang menggunakan masker saat beraktifitas

4. Belum dioptimalkannya pekarangan rumah untuk menanam berbagai tanaman obat.

Terkait pelaksanaannya, anggota tim diberi tanggung jawab tiap satu orang melakukan sosialisasi untuk satu rumah tangga tentunya dengan tetap menerapkan protokol kesehatan Covid-19 seperti menggunakan masker dan menjaga jarak. Pada tahap pelaksanaan, langkah pertama yang dilakukan adalah sosialisasi mengenai covid19 serta bagaimana cara mengantisipasinya. Sosialisasi dilakukan dengan menggunakan media leaflet. Tahapan ini lebih menitik beratkan pada pemberian informasi kepada orang tua di wilayah pengabdian. Orang tua sangat berperan dalam pembentukan sikap yang baik untuk anak, memberikan nilai-nilai dan norma. Jadi, dengan memberikan sosialisasi langsng terhadap orng tua, diharapkanmereka akan lebih menunjukkan perannya dalam memberikan pengendalian dan pengawasan yang tepat dalam menghadapi segala macam marabahaya. Peran orang tua sangat penting dalam menghadapi wabah seperti saat ini. ketika peran keluarga tidak berfungsi dengan baik maka output sosialisasi tidak akan berjalan dengan lancar.

Terdapat beberapa leaflet yang dibagikan, yaitu leaflet mengenai Perilaku Hidup Bersih dan Sehat (PHBS), Gerakan Masyarakat Sehat (GERMAS), Gerakan Menggunakan 
Masker (GEMAS), pembuatan dan penggunaan Antiseptik dan desinfektan, serta Tanaman Obat Keluarga (TOGA). Leaflet dibuat sesuai dengan standar kesehatan yang bersumber dari Dinas Kesehatan. Leaflet dibagikan langsung ke rumah-rumah warga disertai dengan sosialisasi secara langsung pada orang tua di wilayah pengabdian. Metode ini dipilih untuk menghindari perkumpulan dalam skala besar, sebagaimana anjuran pemerintah yaitu melaksanakan physical distancing dan social distancing. Dalam pelaksanaannya, banyak warga yang menanyakan mengenai covid-19 serta bagaimana cara pencegahan dan pengobatannya. Tim yang telah dibekali informasi mengenai covid19 langsung memberikan jawaban terkait pertanyaan-pertanyaan tersebut dengan bahasa yang sesederhana mungkin agar masyarakat lebih mudah memahaminya.
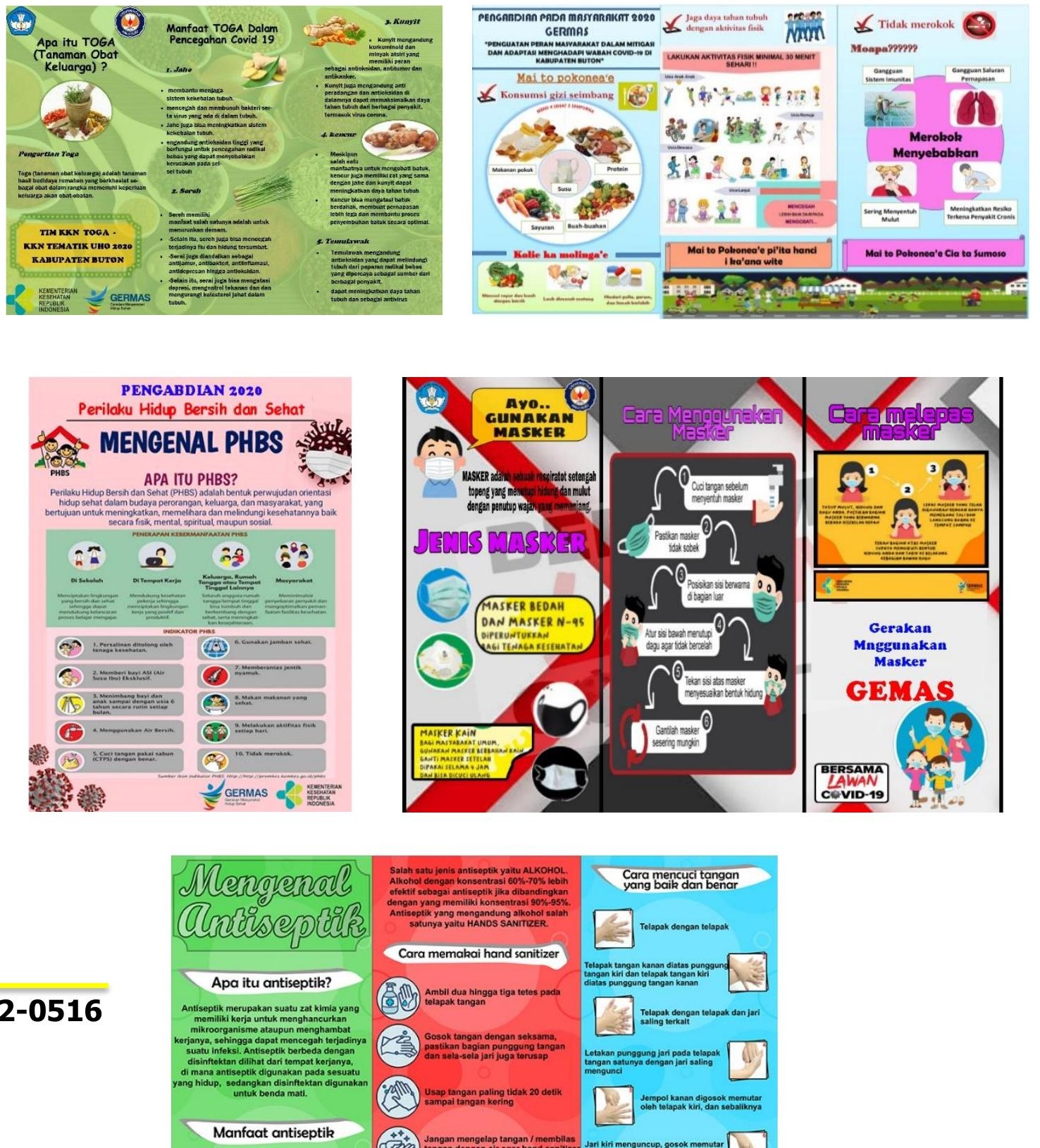


\begin{abstract}
Gambar 1. Leaflet
Pembuatan Leaflet dilakukan agar masyarakat bisa melihat dan membaca beberapa upaya dalam mencegah penyebaran Covid-19 seperti leaflet mengenai penggunaan masker yang baik dan benar serta tindakan-tindakan lain yang termasuk dalam protokol kesehatan Covid-19. Leaflet yang dibuat kemudian disebar melalui media sosial secara online seperti whatsapp, facebook, Instagram dan semacamnya. Penyebaran leaflet juga dilakukan secara offline/langsung ke rumah-rumah warga saat melakukan sosialisasi.

Tahapan berikutnya dari pengabdian ini adalah menyebarkan leaflet mitigasi dan adaptasi menghadapi covid-19 serta perilaku hidup sehat melalui media cetak maupun elektronik, serta grup media sosial wilayah setempat. Hal ini bertujuan agar lebih banyak masyarakat yang memahami bagaimana menghadapi penyebaran covid-19 di era New Normal life.
\end{abstract}



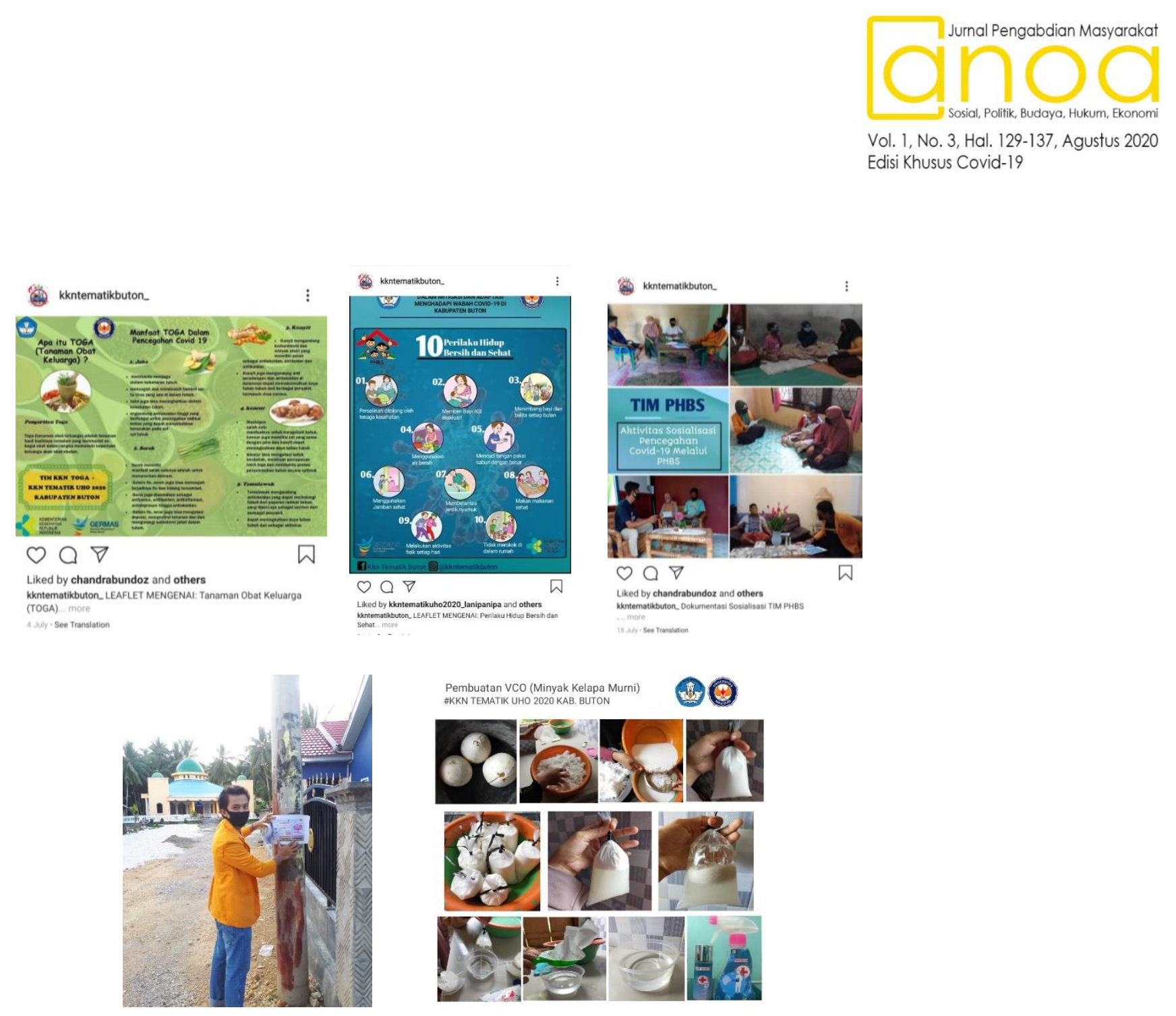

Gambar 2. Penyebaran Informasi melalui media sosial dan penempelan leaflet

Tahapan terakhir dari pelaksanaan pengabdian ini adalah memberikan pemahaman tentang cara pencegahan penyebaran virus, yaitu rutin melakukan penyemprotan desinfektan, pembagian masker dan antiseptik, menanam tanaman obat yang mampu meningkatkan sistem imun, serta olahraga yang rutin. Tim juga menyediakan tempat cuci tangan di sarana publik seperti masjid, pasar dan balai desa. Disekitar jga ditempelkan pamphlet tindakan preventif guna meminimalisir penyebaran covid-19.

Pembagian masker dan handsanitizer dilakukan agar masyarakat yang belum mempunyai masker bisa mendapat bagian dan turut serta dalam mencegah penularan Covid-19 karena dapat melindungi area hidung serta mulut. Pembagian handsanitizer 
dialokasikan kepada pedagang-pedagang yang sering melakukan transaksi jual beli untuk mencegah penularan Covid-19 melalui alat pembayaran barang/jasa (uang).
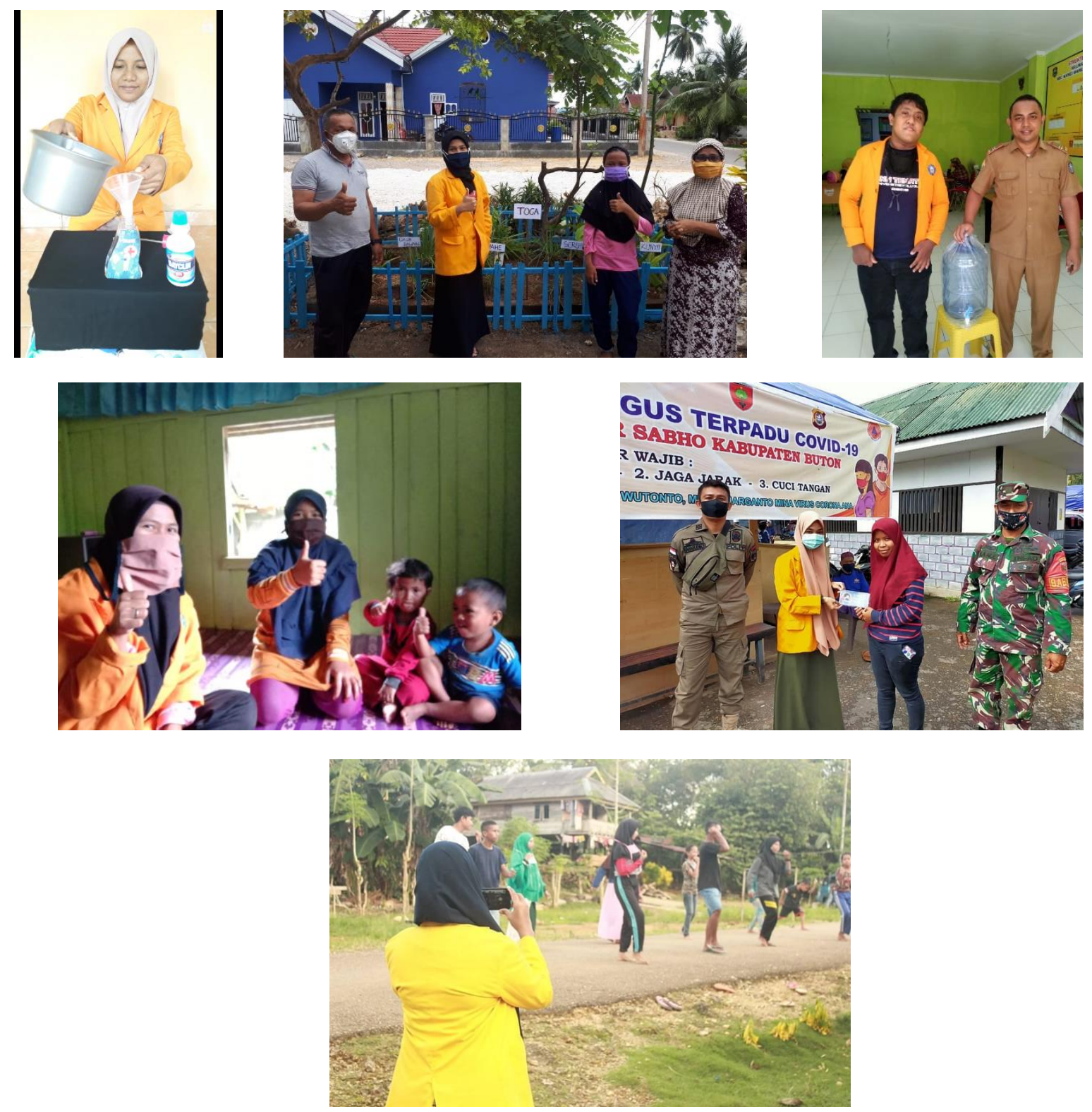

Gambar 3. Kegiatan pembuatan Antiseptik, pembuatan TOGA, penyediaan tempat cuci tangan, pembagian masker, dan olahraga rutin bersama warga

Hasil dari pengabdian ini adalah untuk memberikan informasi kepada masyarakat wilayah Kabupaten Buton dalam mitigasi dan adaptasi menghadapi covid-19. Segala 
usaha yang dilakukan mendapat respon yang sangat positif dari warga di lokasi pengabdian. Warga sangat antusias dan dengan senang hari melakukan langkah-langkah pencegahan yang diinformasikan oleh tim pengabdian.

\section{Kesimpulan}

Berdasarkan hasil dan pembahasan yang sudah disampaikan pada pelaksanaan pengabdian masyarakat terkait penguatan peran masyarakat dalam menghadapi wabah covid-19 di Kabupaten Buton diperoleh bahwa warga masyarakat kabupaten buton memiliki pengetahuan dan kemampuan dalam menghadapi penyebaran covid-19 sehingga lebih waspada dan tenang dalam menghadapi pandemi.

\section{E. Ucapan Terima Kasih}

Tim pengabdian mengucapkan terimakasih kepada Universitas Halu Oleo (UHO) khususnya Lembaga Penelitian dan Pengabdian Masyarakat (LPPM) UHO yang telah membiayai sehingga kegiatan pengabdian masyarakat ini dapat berlangsung dengan baik melalui. Kami juga berterimakasih kepada masyarakat kabupaten buton yang memberikan dukungan dan sambutan yang baik dalam pelaksanaan kegiatan pengabdian masyarakat ini.

\section{DAFTAR PUSTAKA}

Dinas Kesehatan, N. (2020). Pemerintah Serius, Siap dan Mampu Menangani COVID-19 Masyarakat Tetap Tenang \& Waspada. https://corona.ntbprov.go.id/

Koesmawardhani, N. . (2020). Pemerintah Tetapkan Masa Darurat Bencana Corona hingga 29 Mei 2020. https://news.detik.com/berita/d-4942327/ pemerintahtetapkanmasa-darurat-bencana-corona-hingga-29-mei-2020\%0A

Satgas Covid. 2020. Infografis COVID-19 (18 Juli 2020) https://covid19.go.id/p/berita/ infografis-covid-19-18-juli-2020

WHO. (2020). WHO Director-General's remarks at the media briefing on 2019-nCov on 11 February 2020. http://www.who.int/dg/speeches/detail/who-directorgeneralsbriefing-on-2019-ncov-on11-february-2020

Yuliana. (2020). Corona virus diseases (Covid -19); Sebuah tinjauan literatur. Wellness and Healthy Magazine. 